\title{
Determination of Purchase Intensity in Online Shopping: Case on Syiah Kuala University Student
}

Teuku Roli Ilhamsyah PUTRA ${ }^{1}$

Anzan HARIO ${ }^{2}$

\begin{abstract}
This study aims to examine the effect of mediating product risk perceptions on the relationship of shopping experience and the intensity of purchases on Syiah Kuala University students. The data were collected from 150 students using the purposive sampling technique. The results show that online shopping experience has a significant effect on purchasing intensity and product risk perception on students. Product risk perception also has a significant effect on the purchase intensity. Product risk perception is proven to partially mediate the relationship between shopping experience and the purchase intensity on Syiah Kuala University students. The result supports the theories and provides implications for both theory and practice. The limitation of this research is it uses only 3 variables and focuses in one object.
\end{abstract}

KEYWORDS: Shopping Experience, Product Risk Perception, Purchase Intensity.

JEL CLASSIFICATION: $M 3$.

\section{INTRODUCTION}

The growing business world demands every entrepreneur to see opportunities and create competitive advantages. Entrepreneurs must be able to learn and understand consumer behavior. One of them is by doing business using information technology. The development of information technology has a big impact on all aspects, one of which is business development. The development of information technology has changed the way of communication, transactions, trading systems, marketing systems and payment systems. This is because information technology, especially the internet, connects more people, business people, and organizations, and information is easily obtained which makes business today easier and fiercer. According to the Brain Statistics survey in 2015, in 2011 global business online sales reached US \$ 763 trillion. Users on social media reach 2.4 billion users. Internet users are increasing every year showing that business infrastructure with social media and the internet is very promising.

The increasing popularity of the internet and social media has caused business activities around the world to start using the internet and social media. The continued development of the use of social media gives birth to social commerce (Talat et al., 2013). S-commerce is a marketing or business strategy that uses social media tools to market various products and services to consumers in various worlds. S-Commerce used consists of various forms, one of which is Social Network Driven Sales, which is sales and marketing due to the encouragement of social media such as Facebook, Twitter, Instagram. The use of social media for business people aims to build business networks. Business people attract potential

\footnotetext{
${ }^{1}$ Department of Management, Syiah Kuala University, Indonesia, teuku.roli@unsyiah.ac.id

${ }^{2}$ Department of Management, Syiah Kuala University, Indonesia
} 
consumers by marketing the brand, logo, sound of a product in the social media. Continued growth and development of transactions in s-commerce has pushed the intensity of online purchases to increase. The frequency or intensity of online shopping that continues to increase shows that customers feel satisfied on purchases through online media. Shopping intensity is the level of frequency of a consumer doing shopping activities based on feelings of pleasure in the activity (Yuniar \& Nurwidawati, 2013).

Shopping experience is an important factor in consumer shopping behavior. Various direct or indirect interactions that consumers have on a product or service and impressing good or bad will be an experience. Experience in consuming a product or service will affect the customer's purchasing decisions going forward. Experience is one factor in predicting consumer behavior in the future. Good experiences experienced by consumers in shopping online will increase the frequency of shopping going forward.

The experience experienced by consumers will have a major impact on the risk perception of future shopping activities. Risk perception is an assessment of uncertainty faced by consumers (Saraswati, 2012). The risks experienced by consumers include product risk, financial risk, security risk, and functional risk as a result of shopping online. Consumer risk perceptions will be higher in online purchases than in direct purchases by visiting stores. When the customer is aware of the risk of the purchase, the customer's decision to make a purchase will be better considered. Increasing perception and risk assessment in shopping activities will form a higher sense of fear in transactions. It is necessary to have a variety of positive information about an e-commerce web so that it reduces the perceived risk of consumers.

The use of the internet in Indonesia which has increased every year has an impact on changes in various aspects of life. The style and lifestyle of the community, especially adolescents, continues to develop into modern people who want ease in various activities (Parastanti, 2014). The consumer shopping culture is changing traditionally, such as visiting shops, retail, and others turning to shopping online (Online Shopping).

Based on the description above, the researcher wants to conduct a research related to shopping experience, purchases intensity and product risk perception in online shopping.

\section{LITERATURES}

\subsection{Online Shopping Experience}

Same (2012) in Masoud (2013) explains that experience aims to describe various processes, get involved in it, and can influence one's thoughts and emotions through various stimuli. Experience is a common event that occurs in each individual at any time wherever the person is located. Various interactions, which are experienced by consumers of a product or service, the company will give a different reaction based on the experience they have experienced. This experience can affect at different levels (rational, emotional, sensory, physical, and spiritual). Indicators measure Online Shopping Experience according to Kwek, Lau and Tan (2010) through Masoud (2013) there are four indicators, including: 1) Experienced in doing online shopping. 2) Feeling competent when shopping online. 3) The emergence of a comfortable feeling using the web to shop online. 4) Feeling online shopping sites are easy to use. 


\subsection{Product Risk Perception}

Olglethorpe (1994) defines perceptions of risk as consumers' perceptions of the various negative uncertainties that might be experienced in the activities of purchasing a product or service. Indicators Measuring perceptions of risk according to Masoud (2013) there are five indicators, including: 1) The products offered by the online shop are not in accordance with the original. 2) It is difficult to assess the quality of products offered by online shops. 3) The quality of the product is different from what the online shop describes. 4) The performance of products sold by online shops cannot be expected. 5) Size becomes a problem or is not suitable for certain products (such as clothing) if you buy through an online shop.

\subsection{Purchase Intensity}

According to Assael (2003) through Masoud (2013) intensity is repetitive interest in purchase which shows the desire to make continuous purchases. There are four indicators, among others: 1) Making purchases without coercion. 2) Consumer willingness to make repeat purchases. 3) Buy in large quantities. 4) Consistent in buying these products or services even though there are other cheaper competitors.

Following is the testing of the research hypothesis:

H1: The experience of shopping online affects the perception of product risk.

H2: The experience of shopping online affects the intensity of online purchases.

H3: Product risk perception affects the intensity of online purchases.

H4: Online shopping experience influences the intensity of online purchases mediated by product risk perceptions.

The theoretical framework in this study will explain the relationship between each variable and can be seen in Figure 1.

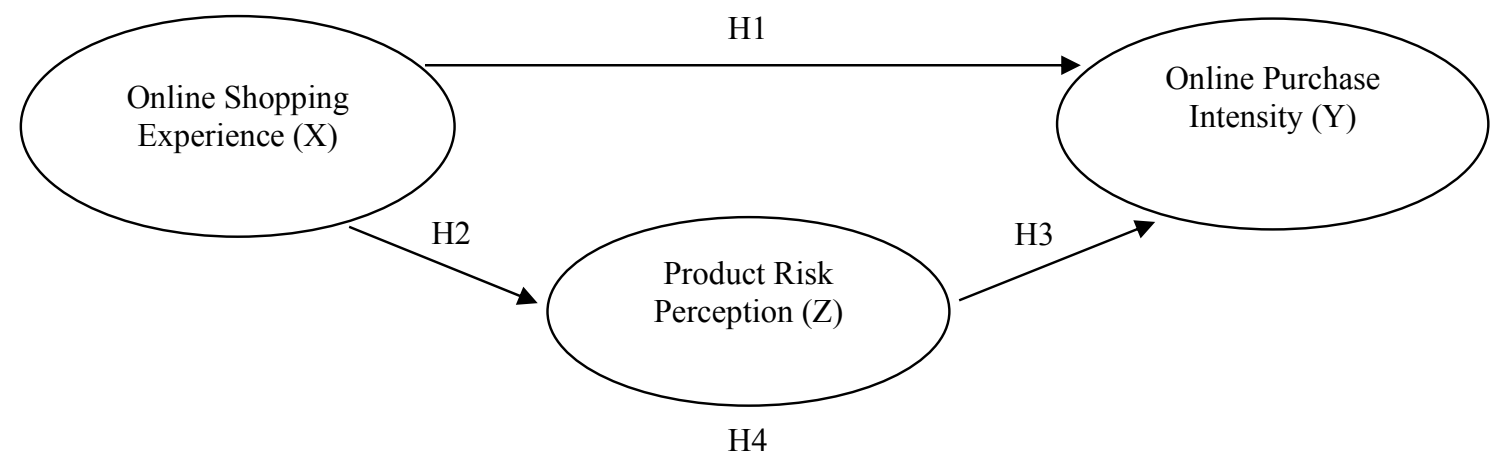

Figure 1. Research Framework

Source: authors

\section{METHOD}

The population in this study is Syiah Kuala University students, is 23,380 as the active students. The retrieval technique of the sample of this study is non probability sampling. The sampling method used is the purposive sampling, with criteria the students must have online shopping experience in recent six months, with the number of samples in this study is 150 to qualify to use path analysis method. In obtaining data and information in accordance with this study, researchers used online questionnaire as a tool that were given privately to respondents. 
The questionnaire is an efficient data collection mechanism if the researcher knows exactly what is needed and how to measure research variables (Sekaran, 2011).

Data analysis equipment used in this study uses the Path Analysis method (Baron and Kenny, 1986). In testing indirect relationships between variables in the model, hierarchical regression has been used. The mediating effect in this study used the Baron and Kenny approaches (in Ghozali, 2011).

\section{RESULT}

Characteristics of respondents based on sex were more dominated by women is about $57.3 \%$ or as many as 86 people from the total respondents, while the rest were male $42.7 \%$ or as many as 68 people from the total respondents.

Furthermore, judging by age, $38.7 \%$ were respondents aged 21 years as many as 58 people. 22 -year-old respondents were $40.7 \%$ or as many as 61 people and 23 years old are 16 people. Respondents aged 19 years, 20 years, and more than 23 years each amount 5 people.

Characteristics of respondents seen from the study program, the most respondents came from Management study programs with a percentage of $47.3 \%$ or as many as 71 people. Next, there are 15 PAUD S1 study program students or $10 \%$ of the total respondents. Respondents from the Bachelor of Law study program are $7.3 \%$ or as many as 11 people, and subsequently the S1 Accounting study program and S1 Pend. Biology is 8 people or $5.3 \%$ of the total. Respondents in the field of S1 Informatics and S1 Pend. Bro. The UK is 5 people each followed by D3 Banking, S1 Medicine, S1 MIPA Physics, S1 Pend. Physics, S1 Pend. Mathematics, S1 Agriculture, and S1 Mechanical Engineering each amounted to 2 people. The rest are respondents who come from Dental Nurse D4, S1. Arabic, S1 Pharmacy, S1 Science Adm. Country, S1 Political Science, S1 Nursing, S1 Pend. Veterinarian, S1 Pend. Dentist, S1 Pend. Economics, S1 Pend. History, Sociology S1, S1 Electrical Engineering, and S1 Chemical Engineering.

The validity test in the research used in the study is the result of a set of indicators obtained from the results of questionnaire distribution so that the resulting data needs to be tested for truth or validity. Testing the validity of the instrument uses the Pearson test product-moment coefficient of correlation. Testing the validity of the questionnaire is based on a comparison of the calculated $r$ values and $r$ table values.

Test the reliability of statement items from a questionnaire using the value of Cronbach Alpha. This is only done once in a group of respondents in each variable. Size reliability is considered reliable based on Cronbach Alpha 0.60 (Malhotra. 2003). If the degree of data reliability is greater than Cronbach Alpha $(\alpha)$, then the measurement results can be considered as a measurement tool with a level of accuracy and consistency of good thinking. Then, each variable use the code SE (shopping experience), PRP (product risk perception), and PI (purchase intensity), that can be seen in Table 1. 
Table 1. Result of Validity \& Reliability Test

\begin{tabular}{|c|c|c|c|c|c|}
\hline No & Item & Variable & $\begin{array}{l}\text { Correlation } \\
\text { Coefficient }\end{array}$ & $\begin{array}{l}\text { Critical Value } \\
5 \%(N=120)\end{array}$ & Cronbach Alpha \\
\hline '/י। & SE1 & \multirow{5}{*}{$\begin{array}{c}\text { Shopping } \\
\text { Experience }(\mathrm{X})\end{array}$} & 0.879 & \multirow{5}{*}{0.1593} & \multirow{5}{*}{0.859} \\
\hline 1 & & & & & \\
\hline 2 & SE2 & & 0.843 & & \\
\hline 3 & SE3 & & 0.887 & & \\
\hline 4 & SE4 & & 0.699 & & \\
\hline 1 & PI1 & \multirow{4}{*}{$\begin{array}{c}\text { Purchase } \\
\text { Intensity (Y) }\end{array}$} & 0.539 & \multirow{4}{*}{0.1593} & \multirow{4}{*}{0.698} \\
\hline 2 & PI2 & & 0.696 & & \\
\hline 3 & PI3 & & 0.858 & & \\
\hline 4 & PI4 & & 0.783 & & \\
\hline 1 & PRP1 & \multirow{5}{*}{$\begin{array}{c}\text { Product Risk } \\
\text { Perception (Z) }\end{array}$} & 0.848 & \multirow{5}{*}{0.1593} & \multirow{5}{*}{0.866} \\
\hline 2 & PRP2 & & 0.728 & & \\
\hline 3 & PRP3 & & 0.789 & & \\
\hline 4 & PRP4 & & 0.887 & & \\
\hline 5 & PRP5 & & 0.800 & & \\
\hline
\end{tabular}

According to Hair et al. (2006) if the scale uses the likert scale, then for the regression coefficient uses the value of the standardized coefficients, where the value of the constant does not need to be interpreted. From the results of SPSS 22.0 output, a linear equation line can be made. The results of the analysis of the influence of shopping experience influence the product risk perception, linear line equations can be made as follows:

PRP $=$ Product Risk Perception

$$
\mathrm{PRP}=0.774(\mathrm{SE})
$$

$\mathrm{SE}=$ Shopping Experience

From the analysis results show that shopping experience affects the perception of product risk with a regression coefficient $(\beta)$ of 0.774 . Then from the regression coefficient value $(\beta)$ it can be explained that when a student has shopping experience (independent) and increases by 1 unit, the perception of product risk will increase by $77.4 \%$. Furthermore, the results of the analysis of the influence of the influence of the Shopping Experience and Risk Perception on Purchase Intensity can be made as follows:

PI = Purchase Intensity

$$
\mathrm{PI}=0.569(\mathrm{SE})-0.421(\mathrm{PRP})
$$

PRP $=$ Product Risk Perception

$\mathrm{SE}=$ Shopping Experience

Shopping experience affects the intensity of purchases with a regression coefficient $(\beta)$ of 0.569 . Then from the regression coefficient $(\beta)$ it can be explained that when a student has shopping experience (independent) and increases by 1 unit, the intensity of his purchase will also increase by $56.9 \%$.

Product Risk Perception affects the intensity of purchases with a regression coefficient $(\beta)$ of negative 0.421 . So from the regression coefficient value $(\beta)$ it can be explained that when a 
student has a perception of product risk and increases by 1 unit, the intensity of the purchase will decrease by $42.1 \%$.

Furthermore, the results of the analysis of the effect of product risk perceptions mediate on the relationship of shopping experience to the intensity of purchases, linear line equations can be made as follows:

$$
\mathrm{PI}=0.569(\mathrm{SE})+-0.421(\mathrm{PRP})
$$

$\mathrm{PI}=$ Purchase Intensity

$\mathrm{SE}=$ Shopping Experience

$\mathrm{PRP}=$ Product Risk Perception

In the second regression equation show the effect of shopping experience decreases from positive significance of 0.895 to positive significant at 0.569 . With the decline in beta after the mediating variable $(Z)$ is tested simultaneously along with the independent variables, it can be said that the effect of mediation between shopping experience on the intensity of purchases is mediated by the perception of product risk. The effect of mediating the perception of risk for this product is partially. Although there is a partial mediating effect of perceptions of product risk at negative 0.421 ; the relationship of shopping experience to the intensity of spending has a stronger relationship than using mediation.

\subsection{Hypothesis Test Result}

Hypothesis testing is done by using the Path Analysis method to determine the effect between variables, which include:

1. Online shopping experience has a positive and significant effect on product risk perceptions as hypothesis 1

2. The online shopping experience has a positive and significant effect on the intensity of online purchases as hypothesis 2

3. Product risk perception has a negative and significant effect on the intensity of online purchases as hypothesis 3

4. The online shopping experience has a positive and significant effect on the intensity of online purchases which is mediated by the perception of product risk as a hypothesis 4 .

The following is an illustration of the variable relationship The experience of online shopping on the intensity of online purchases and perceptions of product risk as a mediating variable can be considered in Figure 2.

The first hypothesis (hypothesis 1) in the study, namely the influence of shopping experience on product risk perceptions showed significant results with the magnitude of the effect of 0.774 . It can be explained that when in a student who has shopping experience and increases 1 unit, the perception of product risk will increase by $77.4 \%$. The adjusted $\mathrm{R}$ square determinant coefficient value of 0.596 explains that shopping experience in explaining variations in perceptions of product risk is $59.6 \%$. While the residual value of the variable role of $40.4 \%$ indicates that there are other factors that influence the perception of product risk on students at the Syiah Kuala University. Students who have experienced online shopping have a lot of product risk experience that has ever been experienced. Consumers who have felt the product from previous purchase activities will be easier to make decisions, and vice versa consumers who have never consumed a product will tend to be careful in the risks that occur and will go 
through many processes in decision making. The more experience in shopping will shape the assessment of the risk of the product to be better.

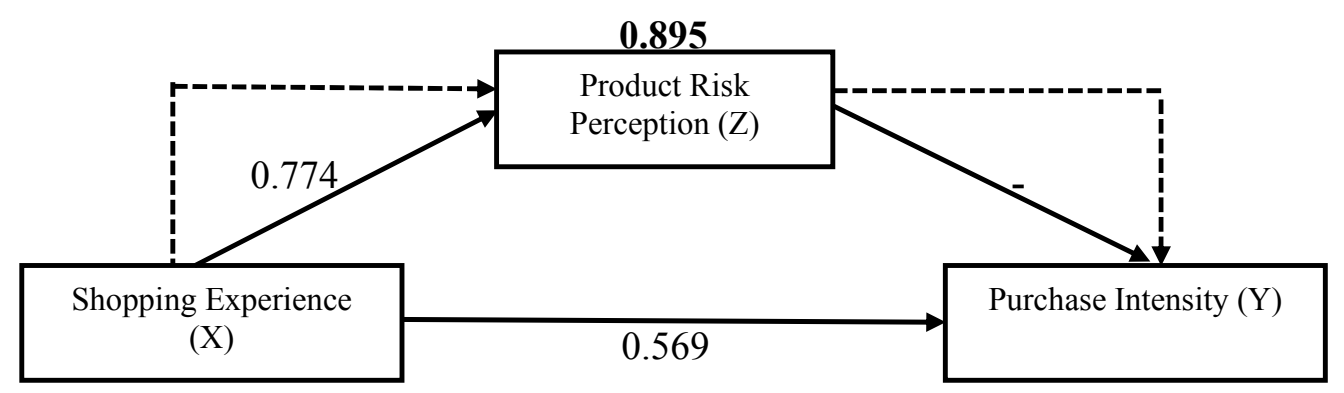

Figure 2. Tested Model

Source: authors

Furthermore, the second hypothesis (hypothesis 2), namely the influence of shopping experience on purchasing intensity shows significant results with the magnitude of the influence of 0.569 . Then it can be explained that when a student has shopping experience and increases 1 unit, the intensity of his purchase will also increase by $56.9 \%$. Syiah Kuala University students who have made online purchases and have more experience in online shopping will make more online purchases. More experienced consumers are facilitated by online shopping without having to visit the market directly. In addition Mohmed (2013) also believes that the experience of buying online online was positively and significantly associated with the intensity of online repurchasing, not only influenced by trust and social behavior. Shim (1990) in Ling, Chai, \& Piew (2010) explains that customers who have frequent and strong purchase intensity in online shopping activities on the internet usually have a good buying experience.

Furthermore, in the third hypothesis (hypothesis 3), the perception of product risk has a significant negative effect on the intensity of purchases. Product risk perception has a negative influence of 0.421 on the intensity of purchases. It can be explained that when a student has a perception of product risk and increases by 1 unit, the intensity of the purchase will decrease by $42.1 \%$. Adjusted $\mathrm{R}$ square value or determinant coefficient value shows a result of 0.869 explaining that shopping experience and risk perception in explaining variations in purchase intensity is $86.9 \%$. While the residual value of the variable is 0.131 (13.1\%) indicating that there are other factors that can affect the intensity of spending on Syiah Kuala University students in addition to the variables in this study. Higher risk perceptions on a product are predicted to have a negative effect on individual intentions to use an online shop that will reduce the intensity of future purchases. The perceived product risk may be higher in the context of online shopping because of the inability of consumers to physically examine the product before buying. However, thanks to the shopping experience that has been done, students have changed the perception of product risk to be better so that the intensity of purchases will increase. Where if in online shopping the product received is not in accordance with the request, the consumer can return the product and be replaced with the appropriate one.

In the last hypothesis (hypothesis 4), the mediation regression equation explains that the regression coefficient Shopping experience increased from positive 0.569 to positive 0.895 . With the increase after the mediation variable $(Z)$ is tested simultaneously along with the independent variables, it can be said that the effect of partial mediation between shopping 
experience on shopping intensity is mediated by product risk perception. The effect of partial mediation is due to the relationship between shopping experience and the purchase intensity which still has a significant influence even though there is no mediation. According to Ling (2010) consumers with a strong intensity of online shopping usually have prior purchasing experience that reduces consumers' risk perception of online shopping. Therefore, the more experienced Syiah Kuala University students in shopping online will make more frequent purchases where the risk of the product is not a matter of too much concern.

\section{CONCLUSIONS}

Based on the explanation of the results described earlier, some conclusions can be drawn from this study as follows:

1. The first hypothesis analysis show that shopping experience has a significant effect of 0.774 on the perception of product risk. It can be explained that when in a student who has shopping experience and increases 1 unit, the perception of product risk will increase by $77.4 \%$. As well, the results of the determination correlation analysis show the value of Adj. R-Square is 0.596 and proves that shopping experience is the dominant factor in influencing product risk perceptions in Syiah Kuala University students. This means that shopping experience gives a picture that can stimulate the perception of product risk in online.

2. The second hypothesis analysis show that shopping experience has a significant effect of 0.569 on the intensity of purchases. Then it can be explained that when a student has shopping experience and increases 1 unit, the intensity of his purchase will also increase by $56.9 \%$. The results of the determination correlation analysis show the value of Adj. R-Square is 0.869. This all means that in online the shopping experience supports purchase intensity.

3. The third hypothesis analysis show the perception of product risk has a significant negative effect of -0.421 on the intensity of purchases. It can be explained that when a student has a perception of product risk and increases by 1 unit, the intensity of the purchase will decrease by $42.1 \%$. This means that product risk perception gives the opposite effect for purchase intensity. When the risk increases in product perception, it will reduce the purchase intensity. The results of the determination correlation analysis show the value of Adj. R-Square is 0.869 and proves the perception of product risk is also the dominant factor in influencing the intensity of purchases.

4. The fourth hypothesis analysis show risk perceptions mediate partially on the relationship of shopping experience to the intensity of purchases. This means that the shopping experience can supports directly the purchase intensity without need to form the product risk perception.

This result supports the theories and provides two implications for both theory and practice as well. For academic, it supports the previous theories, to be an upgrade one as a new premise. The limitation of this research is it uses only 3 variables and focuses in one object. As because this research is conducted in Syiah Kuala University, so, this will be a base for further research to develop, to be extended to other segmentation, or even add other variables to build a new research models. And for the practice, it can be as a reference for business man to consider their business model. This means that every business man now is obliged to pay attention to shopping experience, purchase intensity and product risk perception to enhance their strength to maximize opportunity utilization. 


\section{REFERENCES}

Baron, R. M., Kenny, D. A. (1986). The Moderator-Mediator Variable Distinction in Social Psychological Research: Conceptual, Strategic, and Statistical Considerations. Journal of Personality and Social Psychology, 51(6), 1173-1182.

Ghozali, I. (2011). Aplikasi Analisis Multivariate dengan program SPSS. Undip: Semarang.

Brain Statistics Survey. (2015). https://www.statisticbrain.com/

Ling, K. C., Chai, L. T., \& Piew, T. H. (2010). The Effects of Shopping Orientations, Online Trust and Prior Online Purchase Experience toward Customers' Online Purchase Intention. International Business Research, 3(3), 63-76.

Malhotra, N.K., \& Birks, D.F. (2003). Marketing Research: An Applied Approach. London: Orientation. Prentice Hall.

Masoud, E.Y. (2013).The Effect of Perceived Risk on Online Shopping. European Journal of Business and Management, 5(6).

Parastanti, G. P. (2014). Pengaruh Prior Online Purchase Experience Terhadap Trust Dan Online Repurchase Intention (Survey Pada Pelanggan Zalora Indonesia Melalui Website Www. zalora. co. id). Jurnal Administrasi Bisnis, 16(1).

Saraswati, P., \& Zaki Baridwan, S. E. (2012). Penerimaan Sistem E-Commerce: Pengaruh Kepercayaan, Persepsi Manfaat Dan Persepsi Risiko. Jurnal Ilmiah Mahasiswa FEB, 1(2).

Sekaran, U. (2006). Metodologi Penelitian untuk Bisnis, Edisi 4, Buku 1, Jakarta: Salemba Empat.

Talat, A., Azar. S., \& Yousaf, M. W. (2013). Investigating Social Commerce as an Alternate Model for Online Commerce in Developing Countries: a case of Pakistani Economy. Pakistan Journal of Commerce and Social Science, 7(1), 223-242.

Turban, E., King, D., Lee, J., \& Viehland, D. (2004). Electronic Commerce: A Managerial Perspective. Prentice Hall, New Jersey.

Yuniar, G. S., \& Nurwidawati D. (2013). Hubungan antara Intensitas Penggunaan Situs Jejaring Sosial Facebook dengan Pengungkapan Diri (Self Disclosure) pada Siswasiswi Kelas VIII SMP Negeri 26 Surabaya. Character, 02, pp. 78-84 